\title{
Habitat conditions in streams influence Odonata larval assemblages in the eastern Amazon
}

\author{
Rodrigo Arison Barbosa Ribeiro $\mathbb{1}^{1,2^{*}}$, \\ Leandro Juen (i) ${ }^{1,2}$ \& Leandro Schlemmer Brasil (ib), \\ ${ }^{1}$ Programa de Pós Graduação em Ecologia Aquática e Pesca, Universidade Federal do Pará, \\ Belém, Pará, Brazil \\ ${ }^{2}$ Laboratório de Ecologia e Conservação, Universidade Federal do Pará, Instituto de Ciências \\ Biológicas, Rua Augusto Corrêa, № 1 Bairro Guamá, CEP 66.075-110, Belém, Pará, Brazil \\ *Corresponding author. Email: rodrigoarison@hotmail.com
}

Research Article

O OPEN ACCESS

This article is distributed under the terms of the Creative Commons

Attribution License, which permits unrestricted use, distribution, and reproduction in any medium, provided the original author and source are credited.

Published: 10 January 2022 Received: 19 May 2021

Accepted: 13 October 2021

Citation:

Ribeiro, Juen \&

Schlemmer Brasil (2022): Habitat conditions in stream influence Odonata larvae assemblages in the eastern Amazon. International Journal of Odonatology, 25, 22-30 doi:10.48156/1388.2022.1917160

Data Availability Statement: All relevant data are within the paper and its Supporting Information files.

\begin{abstract}
The growth of agricultural and mining activities in the Amazon has impacted land-use and caused significant changes in the local environmental conditions of streams. In the face of these changes, our study aimed at assessing how environmental changes affect Odonata larval assemblages in streams in the eastern Amazon. We hypothesized that habitat conditions in streams are strong predictors of Odonata larval assemblages. We sampled 30 headwater streams ( $1^{\text {st }}$ through $3^{\text {rd }}$ order) in the eastern Amazon. We corroborated our hypothesis that regional- and local-scale environmental changes are important predictors of the Odonata larval assemblage structure. These results indicate that environmental conditions within the stream channel are important to maintain Odonata larval assemblages, as they provide important resources for larval development. For new studies, we recommend the assessment of temporal dynamics to evaluate whether these patterns are stable across time. Finally, evaluating various environmental scales of the original impact is extremely relevant for preventing the deterioration of or recuperating aquatic assemblages in Amazonian streams, considering the ongoing rapid environmental changes and deforestation in the region. Here we demonstrate that in-stream environmental conditions are important to assemblage structure and this must be considered in environmental restoration plans.
\end{abstract}

Key words. Cattle farming, damselfly, dragonfly, landscape change, land-use, mining

\section{Introduction}

Environmental changes in streams, in limnological characteristics, and in habitat structure have significant effects on aquatic insect assemblages, especially on those that are highly sensitive to environmental changes, such as some species of mayflies (Ephemeroptera), odonates (Odonata), stoneflies (Plecoptera), and caddisflies (Trichoptera) (Castro et al., 2017; Faria et al., 2017; Ferreira et al., 2017; Mendes et al., 2019). Any changes in the abundance or species composition of these taxa in aquatic assemblages are of concern, because they play important roles in nutrient cycles and energy flows (Castro et al., 2019). Odonates are important indicators of habitat quality due to the group's high diversity and sensitivity to environmental changes (Carvalho \& Nessimian, 1998; Mendes et al., 2015). Additionally, because they are predators, they play an important role in aquatic trophic webs (Corbet, 1999; Pires et al., 2020).

Odonates have aquatic larvae and flying terrestrial adult stages. They are extremely abundant and diverse, which allows them to occupy a wide variety of microhabitats in lentic and lotic environments (Corbet, 1999). At their aquatic stage, changes in land-use (Mendes et al., 2017, 2019), habitat structure, and limno- 
logical parameters (e.g., temperature, $\mathrm{pH}$, conductivity, and dissolved oxygen) can result in important changes in assemblage properties, such as richness, species composition, and abundance patterns (Mendes et al., 2017; Pires et al., 2020). These changes in the assemblage structure are related to their physiological needs: the characteristics of thermoregulation in adults (De Marco et al., 2015) and the characteristics of breathing in larval instars (Corbet, 1999). Therefore, changed landscapes usually have a greater impact on adults (De Marco et al., 2015) and in-stream changes more affect the immature stages (Mendes et al., 2017, 2019).

Our study aimed at assessing how environmental changes affect Odonata larval assemblages in streams in the eastern Amazon. We hypothesized that habitat conditions in streams are strong predictors of Odonata larval assemblages. Our hypothesis is based on the premise that in-stream environmental conditions are altered in regions that experience anthropogenic pressures and that this affects aquatic insects (Martins et al., 2018; Castro et al., 2019). This is due to a hierarchical mechanism, where climate and dispersal affect metacommunities on a landscape scale, contributing to regional and biogeographic patterns (Brasil et al., 2019), whereas local habitat characteristics are important for the spatial organization on smaller scales (Montag et al., 2019; Oliveira-Junior et al., 2019).

\section{Material and methods Study area}

Our study was conducted in the Rio Capim river basin, in the municipality of Paragominas, in the southeast of the state of Pará (Figure 1). The region has approximately 150,000 ha of forested area, of which 18,000 are pasturage, 11,000 are Permanent Protection Areas (PPA), 15,000 are areas where logging takes place, and 98,000 ha are native forest. The Capim River basin has a drainage area of around $37,000 \mathrm{~km}^{2}$, mostly due to the slope of the region, and has a roughly rectangular shape (Lima \& Ponte, 2012). The forest rerpesents dense tropical rainforest (Almeida \& Vieira, 2010) in a humid equatorial climate with an average rainfall of $1,743 \mathrm{~mm}$ per annum. The rainy season extends from December through May, and the dry season from June through November (Alvares et al., 2013). The average relative humidity is around $81 \%$, and the average annual temperature is $26.3^{\circ} \mathrm{C}$ (Francez et al., 2009).

Beginning in the second half of the $20^{\text {th }}$ century, the municipality of Paragominas has been suffering high rates of deforestation due to the intensification of anthropogenic activities. As a result, the Rio Capim river basin today displays a mosaic of different land-uses, such as areas for agriculture and cattle farming. All these activities contribute to the deforestation of Bra-
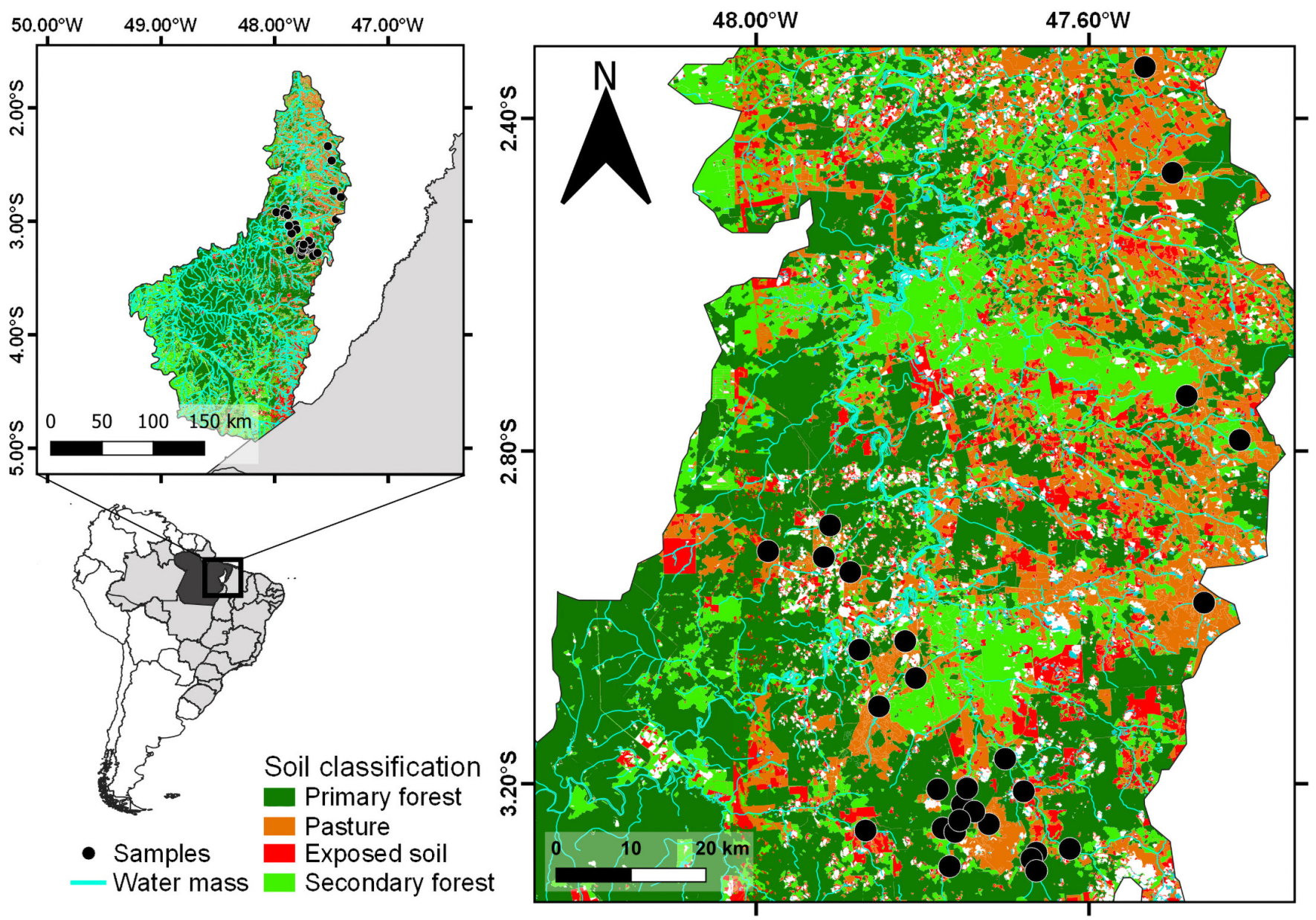

Figure 1. Location of the 30 sampling sites in the Rio Capim river basin in the municipality of Paragominas, state of Pará, Brazil. 
zil's Legal Amazon, which has so far been recorded as amounting to around 80\% (Gardner et al., 2013; Oliveira-Junior et al., 2017).

\section{Sampling design}

The aquatic ecosystems of the Amazon region are highly variable in size and shape. Thus, we standardized our sampling procedure by selecting 30 streams of the first through third orders, according to Strahler's classification (1957). Surveys were carried out in the years of 2015 and 2017, always in the periods of less rainfall to reduce possible seasonal effects. In each stream, we defined a 150-meter stretch divided into 10 sections of 15 meters, each separated by a cross-sectional transect (Figure 2) denominated as " $A$ " through " $K$ " from downstream to upstream.

Within each of the 10 sections, we sampled Odonata larvae and recorded the physical and physicochemical habitat parameters following the physical habitat monitoring and assessment protocol of the United States Environmental Protection Agency (US-EPA) (Kaufmann et al., 1999; Peck et al., 2006). This protocol records environmental information in different categories: availability of shelter for aquatic communities, the structure of riparian vegetation, channel morphology, human impact, and water limnological variables. Evaluating environments according to this protocol has been widely used in ecological studies on assemblies of aquatic in- sects on and in Amazonian streams, and thus has come to be an important tool for assessing the effects of land uses in the Amazon biome (Juen et al., 2016; Mendes et al., 2017, 2018). The physical habitat characterization along each section was carried out following the stream assessment methodology of Peck et al. (2006) and Hughes and Peck (2008). This methodology has already been successfully applied in several studies of Amazonian streams (Juen et al., 2016; Mendes et al., 2019; Montag et al., 2019; Oliveira-Júnior et al., 2019; Dias-Silva et al., 2020).

\section{Biological sampling}

We furthermore subdivided the cross-sectional sections into three five-meter segments for the biological sampling of individuals of which only the first two segments were sampled (Figure 2). Thus, we sampled 20 segments of five meters in width in each stream. Sampling was carried out by sweeping the stream three times from the streambed towards the stream margins using a sieve of $18 \mathrm{~cm}$ of diameter and $250 \mu \mathrm{m}$ in mesh width (Shimano \& Juen, 2016; Mendes et al., 2019). Sampled individuals were taken to the laboratory, preserved in $85 \%$ ethanol, and identified at genus level using taxonomical dichotomous keys (Heckman, 2006; Hamada et al., 2014). To standardize the reliability of sample identification, only organisms that exhibited the development of wing pads reaching the fifth segment

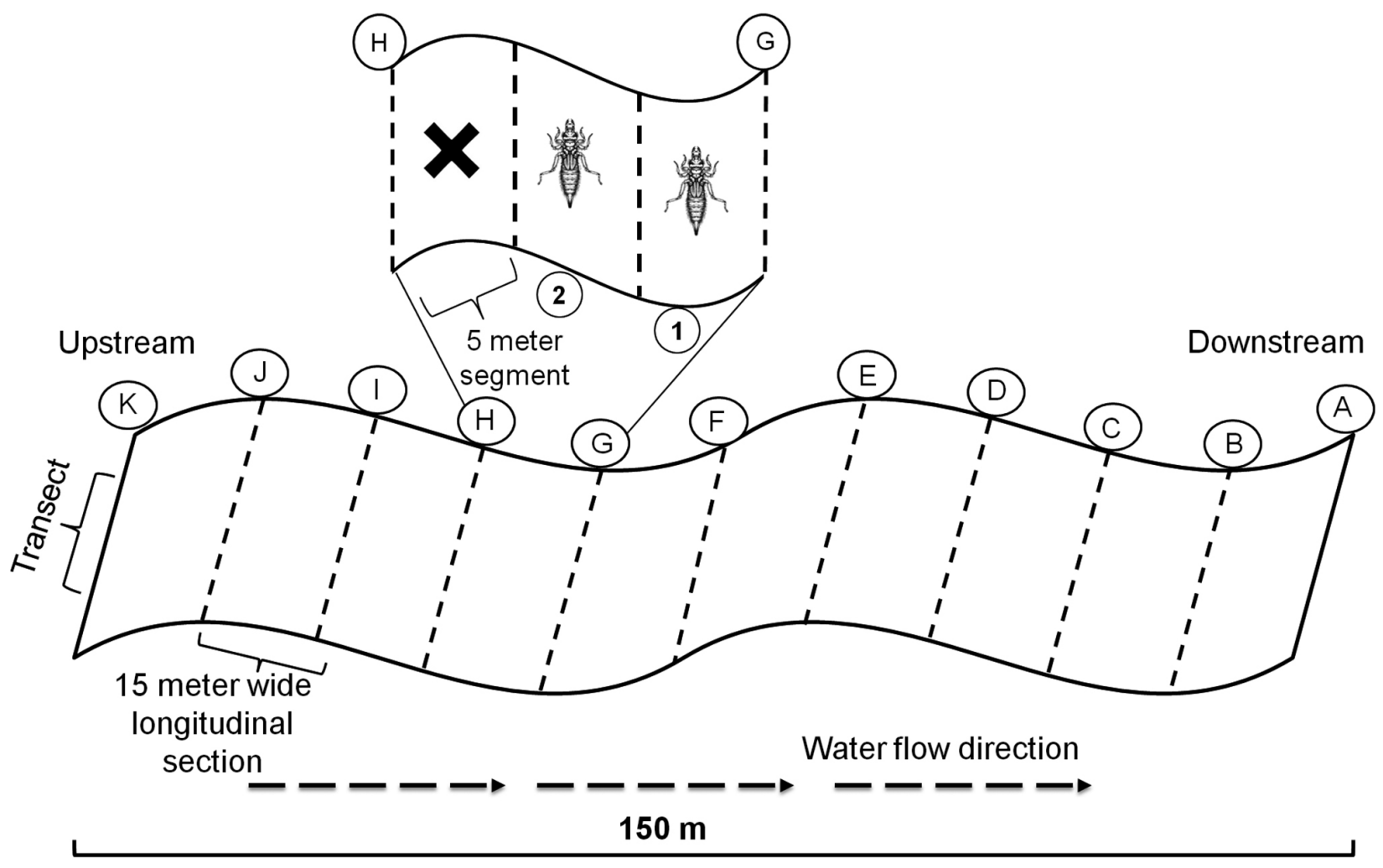

Figure 2. Diagram of the sampling design in each of the sampled streams in the Rio Capim river basin in the municipality of Paragominas, state of Pará, Brazil. We defined a 150-meter transect in each sampled stream, which was then divided into ten 15 -meter sections, each of them separated by a cross transect named " $A$ " through "K" from downstream to upstream. 
of the dorsal abdomen were included (Mendes et al., 2017, 2019). Depending on the species, Odonata larvae may have up to 15 instars, which obstructs larval identification at species level. Because many species do not have their larval instars described, identification at genus level was a recommendation from specialists in the taxonomic classification of Odonata larvae that we followed. Although the taxonomic resolution at genus level is currently considered the best for this group from the Amazon region (Mendes et al., 2017), the identification of some genera has remained quite challenging, and it is not as yet possible to distinguish, for example, individuals of Hetaerina from those of Mnesarete, which were therefore indiscriminately considered Calopterygidae. All sampled organisms were stored in the Zoology Collection of the Federal University of Pará, UFPA (Belém - PA, Brazil).

\section{Characterization of land-uses and vegetation cover}

We used images from the Shuttle Radar Topography Mission (SRTM) project with a resolution of approximately 30 meters. These images were adjusted using images from Google Earth (http://earth.google.com) and TauDem version 5.3 by means of the geoprocessing software QGis version 2.18 (QGIS 157 Development Team, 2017).

The interpretation of the different types of land-uses and vegetation cover was performed using images from the Landsat 8 satellite, using the Semi-Automatic Classification plug-in of the software QGis 2.18 (Macedo et al., 2014). The images were obtained from the United States Geological Survey (USGS) Earth Explorer project in 2015 and 2017. This set of images is essential, since it provides data on the shapes and textures of the different elements of the images for identifying the various types of vegetation cover along the streams (Castro et al., 2017).

To minimize the effects of atmospheric reflectance, we applied a atmospheric correction process to the image set (Antunes et al., 2012). Later, the images were classified into primary and secondary forest areas, pasturage, and areas of exposed soil (where mining activities are concentrated). We validated the classification process by inspecting images from Google Earth (http://earth.google.com). Finally, we cropped a band of 30-meters wide and 600 linear meters in length of riparian zone from each of the stream margins, following the drainage network. This band of vegetation $(30 \times 600 \mathrm{~m})$ is the spatial scale widely used in aquatic ecology studies because it is very important for aquatic biota in Amazonian streams (Montag et al., 2019a, 2019b; Benone et al., 2020; Leão et al., 2020). In addition, 30 meters is the width in which Brazilian law requires the preservation of native vegetation on small streams. Therefore, our landscape matrix was composed of land use percentages such as agriculture and livestock, exposed soil, and native forest. These uses were measured on the spatial scale explained above $(30 \times 600 \mathrm{~m})$.

\section{Physical habitat characterization}

We measured riparian vegetation structure, limnological variables, channel morphology, and anthropogenic impact. Each section was characterized by 10 crosswise equidistant measuring points along the section. We recorded the depth of the thalweg, number of waterretaining objects, presence of fine sediments, slope and sinuosity of the channel, and type of channel. In each of the sections, we measured the depth and type of substrate through visual inspection: sand, clay, consolidated clay, leaf banks, coarse gravel, fine gravel, concrete, rock formations, wood, particulate organic matter, macrophytes, and/or algae, roots, pebbles, and silt.

The limnological parameters temperature, $\mathrm{pH}$, turbidity, dissolved oxygen, total dissolved solids (TDS), and electrical conductivity were measured with the multiparameter probe Horiba ${ }^{\circledR} \mathrm{U}-50$ (Ferreira et al., 2017). Riparian vegetation structure and density were estimated by visually inspecting both margins within a band of $100 \mathrm{~m}^{2}$ for the following three types of vegetation: ground vegetation ( $<0.5 \mathrm{~m}$ height), understory vegetation (0.5-5 $\mathrm{m}$ height), and canopy vegetation (> $5 \mathrm{~m}$ height).

We also assessed habitat complexity in each section through visual inspection of the surface covered by macrophytes, roots, leaves, algae, and wood fragments. We used a spherical densitometer to measure the percentage of canopy cover over the stream main channel in the central portion of each cross transect. We took six measurements in the central portion of each transect: left, right, center, center left, center right, center upstream, center downstream. We took a total of 69 different measurements of the physical habitat in each sampled stream based on Kaufmann et al. (1999) (Supplementary material S4).

\section{Data analysis}

We performed a "forward selection" of the R software ( $\mathrm{R}$ Core Team, 2020) adespatial package (Dray et al., 2018) for the variables that best explain the variation in Odonata assemblages to reduce the number of habitat and landscape variables (Blanchet et al., 2008). This selection uses the species matrix and the matrix of environmental predictors and was suggested by Borcard et al. (2018) for the selection of variables to reduce the residual portion in analyses such as RDA and CCA. After that, to avoid autocorrelation among the selected variables, we applied Spearman correlations to exclude highly correlated environmental variables ( $\rho s \geq 0.70$ ). We kept the one with greatest importance to odonate assemblages for each pair of highly correlated variables. This prior variable selection procedure is important to reduce the residual variability of our final explanatory 
model, which could be inflated by a high number of predictor variables (Legendre \& Legendre, 2012). We considered each stream our sample units and the assemblage data, and we summed up the abundances recorded in all sampled segments within the same stream. More details on environmental variables are provided in Supplementary material.

We ran a Redundancy Analysis (RDA) to verify the relationship between assemblages and Odonata genera with the environmental variables selected in the previous step. To do so, we used these environmental variables as predictor and the genera composition as our response matrix. Before running the analysis, we Hellinger-transformed our abundance data (Legendre \& Gallagher, 2001) to maximize the explanatory power of our model (i.e., adjusted $\mathrm{R}^{2}$ ) (Peres-Neto et al., 2006). We built a biplot using the RDA axes to visualize the association between the most important environmental predictors and the odonate assemblages. We also applied ANOVA to test for the linear effects of the environmental predictors on the main RDA axis, which represents the biotic matrix (Legendre \& Legendre, 2012).

Finally, to directly test the relationship of Odonata communities with environmental conditions and to complement what was seen in the RDA, we carried out a Mantel test. The Mantel test was performed with a species composition matrix with abundance data using the Braycurtis distance and with a matrix with environmental variables using the Euclidean distance. All analyses were run in the 'vegan' package, ver. 2.5-6 (Oksanen et al., 2020), adopting $\alpha=0.05$.

\section{Results \\ Assemblage description}

We sampled a total of 444 individuals representing 37 genera, of which $11(29.7 \%)$ genera and $115(25.9 \%)$ individuals were damselflies, and 26 (70.3\%) genera and $329(74.1 \%)$ individuals were dragonflies. Most abundant among the nine families we sampled were Gomphidae (Anisoptera), with $42.34 \%$ of the individuals, followed by Libellulidae (Anisoptera) and Coenagrionidae (Zygoptera) with $26.58 \%$ and $18.69 \%$ of the individuals sampled, respectively.

The most abundant genera of the Gomphidae were Zonophora (Selys, 1854), with 55 individuals (29.25\%), Progomphus (Selys, 1854), with 45 individuals (23.94\%), Phyllogomphoides (Belle, 1970), with 37 individuals (19.68\%), and Phyllocycla (Calvert, 1978), with 30 individuals sampled (15.96\%). The genera Gynothemis (Calvert in Ris, 1909) (21.19\%) and Oligoclada (Karsch, 1890) $(20.34 \%)$ were the most abundant ones within the Libellulidae, with 25 and 24 individuals, respectively. The genera Acanthagrion (Selys, 1876) and Argia (Rambur, 1842) were the most abundant ones within the Coenagrionidae with 24 individuals $(28.91 \%)$ sampled each (Supplementary material S1).
Table 1. "Forward selection" results for the environment predictors related to larval odonate assemblages on streams in the Rio Capim river basin, in the municipality of Paragominas, Pará, Brazil. AdjR $R^{2}$ adjusted $R^{2}$.

\begin{tabular}{|c|c|c|c|}
\hline Variable & Code & $\operatorname{Adj}^{2}$ & $\mathbf{P}$ \\
\hline $\begin{array}{l}\text { Average intermediate woody } \\
\text { canopy }\end{array}$ & XCMW & 0.072 & $<0.001$ \\
\hline Temperature & TEMP & 0.117 & 0.003 \\
\hline $\begin{array}{l}\text { Average natural shelter (leaf banks } \\
\text { and live roots) }\end{array}$ & XFC_LIF & 0.150 & 0.013 \\
\hline Volume of wood in the streambed & V3W_150 & 0.180 & 0.020 \\
\hline Percentage of algae & PCT_AL & 0.208 & 0.022 \\
\hline $\begin{array}{l}\text { Proportion of shelter at excavated } \\
\text { margins }\end{array}$ & PFC_UCB & 0.208 & 0.050 \\
\hline $\begin{array}{l}\text { Proportion of human impact per } \\
\text { section }\end{array}$ & X_HAG & 0.260 & 0.011 \\
\hline
\end{tabular}

\section{Association between assemblages and the environ- mental predictors}

The "forward selection" procedure selected seven local environmental variables that apparently were related to the odonate assemblages: average intermediate woody canopy, average natural shelter, percentage of algae, proportion of human impact per section, proportion of shelter at excavated margin, temperature, and volume of wood in the streambed (Table 1).

When we looked into the association between environmental predictors and odonate assemblages, we found that they explained $25 \%$ of the variation contained in the first two RDA axes (ANOVA for test linearity relationship between environmental and biotic matrix; $\mathrm{F}=2.45 ; \mathrm{df}=7 ; p<0.001$ ). Both axes were negatively affected by temperature and the volume of wood in the streambed and positively affected by natural shelters (leaf banks and live roots) (Supplementary material S2). According to the Mantel test, used as a complement to the RDA, the environmental variables together explained $24 \%\left(\mathrm{R}_{\text {Mantel }}=0.245 ; p=0.001\right)$ of the distribution of Odonata communities in the streams analyzed.

The RDA graphical representation of the association between the Odonata larvae assemblage and local and regional environmental variables showed, in the first axis, a gradient from streams with larger amounts of woody vegetation (negatively related) to those with higher variation in algae percentage (positively related) (Figure 3). The genera Aeschnosoma and Phyllocycla were closely related to streams with a higher variability in the amount of algae. However, the second axis showed a gradient from streams with higher water temperatures (negatively related) to streams with a higher variability in natural shelters, such as leaf banks and roots (positively related). The genus Zonophora was more closely related to streams with a larger number of natural shelters and a higher percentage of algae (Figure 3). 


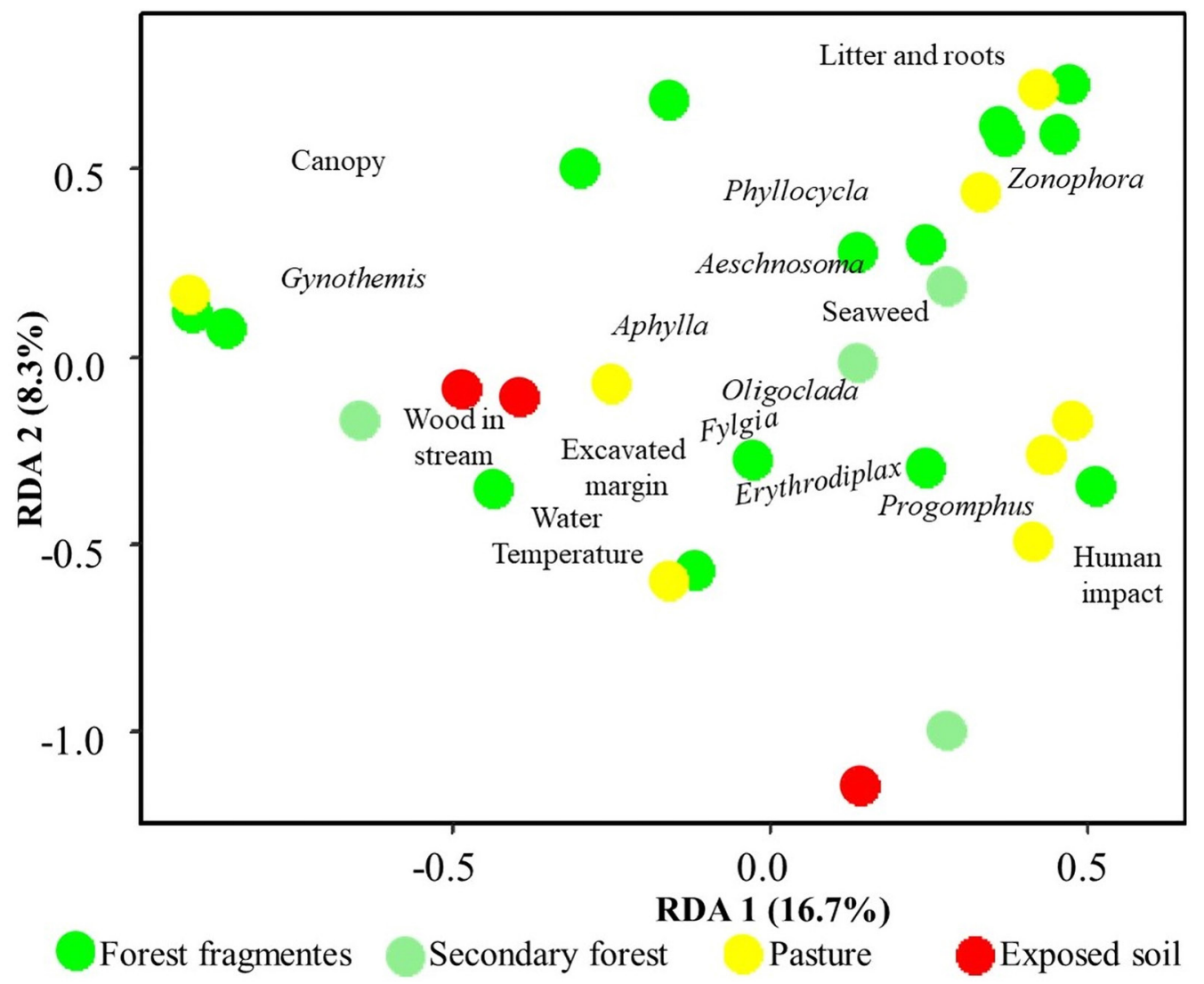

Figure 3. Redundancy analysis (RDA) plot showing the associations between local habitat predictors and landscape predictors with the Odonata larval assemblage. Different colors represent the different land-use types: Dark green: forest fragments; Light green: secondary forest; Yellow: pasturage; Red: exposed soil.

\section{Discussion}

The variation in Odonata larval assemblages is explained by the composition of the local habitat, supporting our hypothesis. This is a recurring pattern in studies that investigate the effects of environmental change on fish (Montag et al., 2019) and aquatic insect assemblages in tropical streams, such as mayfly, stonefly, and caddisfly assemblages (Siegloch et al., 2017), and adult odonate assemblages (Oliveira-Junior et al., 2019). Although changes in the landscape affect in-stream conditions (Leal et al., 2018), all the evidence cited above, together with our results, suggest that changes at small spatial scales (in-stream) are the ones that most directly affect aquatic diversity.

All environmental predictors that were important in explaining assemblage variability were related to the stream marginal vegetation cover (canopy cover, hanging vegetation, leaf banks and roots, and wood fragments within the channel). Other predictors may be indirectly affected by deforestation, such as water temperature, which can increase due to intensified insolation (Carvalho et al., 2013), decrease in thalweg depth due to higher sediment deposition (Wood \& Armitage, 1997; Couceiro et al., 2010), increase in stream margin excavation due to the lack of protecting vegetation (Oliveira-Junior et al., 2017), and human impact, which is most severe in the form of deforestation (Sonter et al., 2017).
The local environmental changes caused by the alteration of landscapes due to multiple land-uses were important predictors of the variation in Odonata larval assemblages (Juen et al., 2014; García-García et al., 2017; Mendes et al., 2018). A possible explanation for this finding is that adult odonates are dependent on the physical habitat structure, such as canopy cover and hanging vegetation (Vianna \& De Marco, 2012; Mendes et al., 2017). Studies that considered both larval and adult odonate assemblages in Brazilian streams found congruences in the spatial distribution of these two life stages, which varied from $>50$ to $>90 \%$ (Valente-Neto et al., 2016; Mendes et al., 2017). Therefore, it is expected that environmental predictors related to light exposure, such as canopy cover (De Marco et al., 2015), and the presence of perches, such as hanging vegetation (Rodrigues et al., 2019), which mostly affect adults, would also indirectly affect the spatial distribution of their larvae.

All taxa with the strongest relation to environmental variables were dragonflies (see Figure 3 and Supplementary material S3). This group is more tolerant of environmental variation and potentially more inclined to colonizing habitats that are distant from those where they emerged (Corbet, 1999). Thus, they will benefit from the presence of open areas in that it facilitates higher foraging activity and offers a higher potential for dispersal and the colonization of new habitats for 
larval development (De Marco \& Latini, 1998; Corbet, 1999). The removal of marginal vegetation also caused the transport of allochthonous debris and the growth of macrophytes and algae, which can favor the occurrence of certain dragonfly genera (Mendes et al., 2019). For example, the Zonophora and Progomphus individuals were positively affected by the extent of human impact on marginal vegetation. We believe this happened because these organisms are fossorial and have a predilection for substrates with higher sediment deposition (Corbet, 1999; Carvalho \& Nessimian, 1998). Therefore, because they have a narrower tolerance response to environmental changes, some dragonflies exhibit a lower dependence on habitat integrity for both colonization and development on both regional and local scales.

Our results demonstrate that local-scale habitat filters can affect the structure of Odonata larval assemblages along the microbasin. We believe that the alteration of environments may be a determinant for the contrasting results we obtained regarding the numbers of genera and individuals of the two odonate suborders. Finally, we suggest more studies that consider different spatial scales (local and regional) be conducted in regions that are subject to multiple land-use types. Also, if possible, we suggest measuring the temporal dynamics of those landscapes and the behavior and preferences of Odonata larvae, as they are of fundamental importance for filling the knowledge gaps concerning the effects of landscape changes on the environmental conditions of streams and their biological diversity.

\section{Acknowledgments}

We thank the Consortium BRC and the Hydro Alunorte Company for their funding and logistical support. We also thank the National Council for Scientific and Technological Development (CNPq) for its funding for the projects "Influência dos diferentes tipos de uso do solo sobre a biodiversidade na Amazônia Oriental" (Grant \#449315/2014-2) and "Tempo de resiliência das comunidades aquáticas após o corte seletivo de madeira na Amazônia Oriental" (Grant \#481015/2011-6). RG would like to thank the Coordination for the Improvement of Higher Education Personnel (CAPES) for a research fellowship (Grant\#88882.444769/2019-01). LJ would also like to thank the National Council for Scientific and Technological Development $(\mathrm{CNPq})$ for a research productivity fellowship (Grant \#304710/2019-9). We furthermore thank the Pró-Reitoria de Pesquisa e Pós-Graduação (PROPESP) from the Federal University of Pará (UFPA) (Edital 01/2020) for funding the revision of the manuscript into English. We also thank Ana Luiza Andrade, Ana Luisa Fares, Carina Kaory Saahara de Paiva, Calebe Maia, Gilberto Nepomuceno Salvador, Lenize Batista Calvão, Naiara Raiol Torres, Thaísa Michelan, and Thiago Augusto Pedroso Barbosa for helping us with the biological sampling. This paper is number BRC0036 in the publication series of the BRC.

\section{References}

Almeida, A. S. D. \& Vieira I. C. G. (2010). Centro de Endemismo Belém, status da vegetação remanescente e desafios para a conservação da biodiversidade e restauração ecológica. Revista de Estudos Universitários, 36(3), 95-111.
Alvares, C. A., Stape, J. L., Sentelhas, P. C., de Moraes Gonçalves, J. L. \& Sparovek, G. (2013). Köppen's climate classification map for Brazil. Meteorologische Zeitschrift, 22(6), 711-728. doi: 10.1127/ 0941-2948/2013/0507

Antunes, M. A. H., Debiasi, P., Costa, A. R. \& Gleriani, J. M. (2012). Correção Atmosférica de Imagens Alos/Avnir-2 Utilizando o Modelo 6S. Revista Brasileira de Cartografia, 63(4), 531-539.

Benone, N. L., Soares, B. E., Lobato, C. M. C., Seabra, L. B., Bauman, D. \& de Assis Montag, L. F. (2020). How modified landscapes filter rare species and modulate the regional pool of ecological traits? Hydrobiologia, 1-16. doi:10.1007/s10750020-04405-9

Blanchet, F. G., Legendre, P. \& Borcard, D. (2008). Forward selection of explanatory variables. Ecology, 89(9), 2623-2632. doi:10. 1890/07-0986.1

Borcard, D., Gillet, F. \& Legendre, P. (2018). Canonical ordination. In Borcard, D., Gillet, F. \& Legendre, P. (Eds.), Numerical ecology with R. pp. 203-297. Springer, Cham. doi: 10.1007/978-3-31971404-2 6

Brasil, L. S., Silverio, D. V., Cabette, H. S. R., Batista, J. D., Vieira, T. B., ... Juen, L. (2019). Net primary productivity and seasonality of temperature and precipitation are predictors of the species richness of the Damselflies in the Amazon. Basic and applied ecology, 35, 45-53. doi:10.1016/j.baae.2019.01.001

Carvalho, A. L. \& Nessimian, J. L. (1998). Odonata do Estado do Rio de Janeiro, Brasil: hábitats e hábitos das larvas. Oecologia brasiliensis, 5(1), 1. doi:10.4257/oeco.1998.0501.01

Carvalho, F. G. D., Pinto, N. S., Oliveira Junior, J. M. B. D. \& Juen, L. (2013). Effects of marginal vegetation removal on Odonata communities. Acta Limnologica Brasiliensia, 25(1). 10-18. doi:10.1590/S2179-975X2013005000013

Castro, D. M. P., Callisto, M., Solar, R. R. C., Macedo, D. R. \& Fernandes, G. W. (2019). Beta diversity of aquatic invertebrates increases along an altitudinal gradient in a Neotropical mountain. Biotropica, 51(3), 399-411. doi:10.1111/btp.12660

Castro, D. M. P., Dolédec, S. \& Callisto, M. (2017). Landscape variables influence taxonomic and trait composition of insect assemblages in Neotropical savanna streams. Freshwater Biology, 62(8), 1472-1486. doi:10.1111/fwb.12961

Corbet, P. (1999). Dragonflies: Behaviour and Ecology of Odonata. Harley Books, Ithaca, New York.

Couceiro, S. R. M., Hamada, N., Forsberg, B. R. \& Padovesi-Fonseca, C. (2010). Effects of anthropogenic silt on aquatic macroinvertebrates and abiotic variables in streams in the Brazilian Amazon. Journal of Soil and Sediments, 10(1), 89-113. doi:10.1007/ s11368-009-0148-z

De Marco, P. \& Latini, A. O. (1998). Estrutura de guildas e riqueza de espécies em uma comunidade de larvas de Anisoptera (Odonata). Ecologia de Insetos Aquáticos. Series Oecologia Brasiliensis, 5, 101-112. doi:10.1371/journal.pone.0123023

De Marco, P. D. M., Batista, J. D. \& Cabette, H. S. R. (2015). Community assembly of adult odonates in tropical streams: an ecophysiological hypothesis. PLoS One, 10(4), e0123023. doi:10.1371/ journal.pone.0123023

Dias-Silva, K., Brasil, L. S., Juen, L., Cabette, H. S. R., Costa, C. C., Freitas, P. V. \& de Marco, P. (2020). Influence of local variables and landscape metrics on Gerromorpha (Insecta: Heteroptera) assemblages in savanna streams, Brazil. Neotropical Entomology, 49(2), 191-202. doi:10.1007/s13744-019-00748-8

Dray, S., Bauman, D., Blanchet, G., Borcard, D., Clappe, S., Guenard, G., Jombart, T., Larocque, G., Legendre, P., Madi, N. \& Wagner, H. H. (2018). Adespatial: multivariate multiscale spatial analysis. $R$ package version 0.3-14. https://CRAN.R-project.org/ package $=$ adespatial 
Faria, A. P. J., Ligeiro, R., Callisto, M. \& Juen, L. (2017). Response of aquatic insect assemblages to the activities of traditional populations in eastern Amazonia. Hydrobiologia, 802(1), 39-51. doi:10.1007/s10750-017-3238-8

Ferreira, W. R., Hepp, L. U., Ligeiro, R., Macedo, D. R., Hughes, R. M., Kaufmann, P. R. \& Callisto, M. (2017). Partitioning taxonomic diversity of aquatic insect assemblages and functional feeding groups in neotropical savanna headwater streams. Ecological Indicators, 72, 365-373. doi:10.1016/j.ecolind.2016.08.042

Francez, L. M. B., Carvalho, J. O. P., Jardim, F. C. S., Quanz, B. \& Pinheiro, K. A. O. (2009). Efeito de duas intensidades de colheita de madeira na estrutura de uma floresta natural na região de Paragominas, Pará. Acta Amazonica, 39, 851-863. doi:10.1590/ S0044-59672009000400014

García-García, P. L., Vázquez, G., Novelo-Gutiérrez, R. \& Favila, M. E. (2017). Effects of land-use on larval Odonata assemblages in cloud forest streams in central Veracruz, Mexico. Hydrobiologia, 785(1), 19-33. doi:10.1007/s10750-016-2900-x

Gardner, T. A., Ferreira J., Barlow J., Lees, A. C., Parry, L. \& Vieira, I. C. G. (2013). A social and ecological assessment of tropical landuses at multiple scales: the Sustainable Amazon Network. Philosophical Transactions of the Royal Society B: Biological Sciences, 368(1619), 20120166. doi:10.1098/rstb.2012.0166

Hamada, N., Nessimian, J. L. \& Querino, R. B. (2014). Insetos aquáticos na Amazônia brasileira: taxonomia, biologia e ecologia. Manaus: Editora do INPA, 2014.

Heckman, C. W. (2006) Encyclopedia of South American aquatic insects, Odonata-Anisoptera, illustrated keys to known Families, Genera, and Species in South America. Springer Science \& Business Media.

Hughes, R. M. \& Peck, D. V. (2008). Acquiring data for large aquatic resource surveys: the art of compromise among science, logistics, and reality. Journal of the North American Benthological Society, 27(4), 837-859. doi:10.1888/08-028.1

Juen, L., Cunha, E. J., Carvalho, F. G., Ferreira, M. C., Begot, T. O., ... Montag, L. F. A. (2016). Effects of oil palm plantations on the habitat structure and biota of streams in Eastern Amazon. River Research and Applications, 32(10), 2081-2094. doi:10.1002/rra.3050

Juen, L., Oliveira-Júnior, J. M. B., Shimano, Y., Mendes, T. P. \& Cabette, H. S. R. (2014). Composição e riqueza de Odonata (insecta) no ecótone Cerrado-Floresta Amazônica em riachos com diferentes níveis de conservação. Acta Amazon, 44(2), 175-184. doi:10.1590/S0044-59672014000200008

Kaufmann, P. R., Levine, P., Robison, E. G., Seeliger, C. \& Peck, D. V. (1999). Quantifying physical habitat in wadeable streams. EPA/620/R-99/003. US Environmental Protection Agency, Washington, DC, 130.

Leal, C. G., Barlow, J., Gardner, T. A., Hughes, R. M., Leitão, R. P., ... Ferreira, J. (2018). Is environmental legislation conserving tropical stream faunas? A large-scale assessment of local, riparian and catchment-scale influences on Amazonian fish. Journal of Applied Ecology, 55(3), 1312-1326. doi:10.1111/1365-2664.13028

Leão, H., Siqueira, T., Torres, N. R. \& de Assis Montag, L. F. (2020). Ecological uniqueness of fish communities from streams in modified landscapes of Eastern Amazonia. Ecological Indicators, 111, 106039. doi:10.1016/j.ecolind.2019.106039

Legendre, P. \& Gallagher, E. D. (2001). Ecologically meaningful transformations for ordination of species data. Oecologia, 129(2), 271-280. doi:10.1007/s004420100716

Legendre, P. \& Legendre, L. F. (2012). Numerical ecology (Vol. 24). Elsevier.

Lima, A. M. M. \& Pontes, M. X. (2012). Dinâmica da paisagem da Bacia do Rio Capim-PA. Revista Brasileira de Geografia Física, 5(1), 127-142. doi:10.26848/rbgf.v5i1.232779
Macedo, D. R., Hughes, R. M., Ligeiro, R., Ferreira, W. R., Castro, M. A., Junqueira, N. T., Oliveira, D. R., Firmiano, K. R., Kaufmann, P. R., Pompeu, P. S. \& Callisto, M. (2014). The relative influence of catchment and site variables on fish and macroinvertebrate richness in cerrado biome streams. Landscape Ecology, 29(6), 10011016. doi:10.1007/s10980-014-0036-9

Martins, W. B. R., Ferreira, G. C., Souza, F. P., Dionísio, L. F. S. \& Oliveira, F. A. (2018). Deposição de serrapilheira e nutrientes em áreas de Mineração submetidas a métodos de restauração florestal em Paragominas, Pará. Floresta, 48(1), 37-48. doi:10.5380/ rf.v48i1.49288

Mendes, T. P., Benone, N. L. \& Juen, L. (2019). To what extent can oil palm plantations in the Amazon support assemblages of Odonata larvae? Insect Conservation and Diversity, 12(5), 448-458. doi:10.1111/icad.12357

Mendes T. P., Cabette, H. S. R \& Juen, L. (2015). Setting boundaries: Environmental and spatial effects on Odonata larvae distribution (Insecta). Anais da Academia Brasileira de Ciências, 87(1), 239-248. doi:10.1590/0001-3765201520130477

Mendes, T. P., Luiza-Andrade, A., Cabette, H. S. R. \& Juen, L. (2018). How does environmental variation affect the distribution of dragonfly larvae (Odonata) in the Amazon-Cerrado Transition Zone in Central Brazil? Neotropical Entomology, 47(1), 37-45. doi:10.1007/s13744-017-0506-2

Mendes, T. P., Oliveira-Junior, J. M. B., Cabette, H. S. R., Batista, J. D. \& Juen, L. (2017). Congruence and the biomonitoring of aquatic ecosystems: are odonate larvae or adults the most effective for the evaluation of impacts. Neotropical entomology, 46(6), 631641. doi:10.1007/s13744-017-0503-5

Montag, L. F., Leão, H., Benone, N. L., Monteiro-Júnior, C. S., Faria, A. P. J., ... Winemiller, K. O. (2019b). Contrasting associations between habitat conditions and stream aquatic biodiversity in a forest reserve and its surrounding area in the Eastern Amazon. Hydrobiologia, 826(1), 263-277. doi:10.1007/s10750-0183738-1

Montag, L. F., Winemiller, K. O., Keppeler, F. W., Leão, H., Benone, N. L., ... Lopez-Delgado, E. O. (2019a) Land cover, riparian zones and instream habitat influence stream fish assemblages in the eastern Amazon. Ecology of Freshwater Fish, 28(2), 317329. doi:10.1111/eff.12455

Oksanen, J., Blanchet, F. G., Friendly, M., Kindt, R., Legendre, P., McGlinn, D., Minchin, P. R., O'Hara, R. B., Simpson, G. L., Solymos, P., Stevens, M. H. H., Szoecs, E. \& Wagner, H. (2020). Vegan: community ecology package. $R$ package version 2.5-6. https:// CRAN.R-project.org/package=vegan

Oliveira-Junior, J. M. B., De Marco, P., Dias-Silva, K., Leitão, R. P., Leal, ... Juen, L. (2017). Effects of human disturbance and riparian conditions on Odonata (Insecta) assemblages in eastern Amazon basin streams. Limnologica, 66, 31-39. doi:10.1016/j. limno.2017.04.007

Oliveira-Junior, J. M. B., Dias-Silva, K., Teodósio, M. A. \& Juen, L. (2019). The response of Neotropical dragonflies (Insecta: Odonata) to local and regional abiotic factors in small streams of the Amazon. Insects, 10(12), 446. doi:10.3390/insects10120446

Peck, D. V., Herlihy, A. T., Hill, B. H., Hughes, R. M., Kaufmann, P. R., ... Magee, T. (2006). Environmental monitoring and assessment program-surface waters western pilot study: field operations manual for wadeable streams. EPA 600/R-06/003.

Peres-Neto, P. R., Legendre, P., Dray, S. \& Borcard, D. (2006). Variation partitioning of species data matrices: estimation and comparison of fractions. Ecology, 87(10), 2614-2625. doi:10.1890/00129658(2006)87[2614:VPOSDM]2.0.CO;2

Pires, M. M., Siegloch, A. E., Hernández, M. I. M. \& Petrucio, M. M. (2020). Environmental drivers and composition of assemblages 
of immature odonates (Insecta) in a subtropical island in southern Brazil. Acta Limnologica Brasiliensia, 32. doi:10.1590/s2179$975 \times 8017$

QGIS Development Team. (2017). QGIS Geographic Information System. Open Source Geospatial Foundation Project. qgis.org/de/ site/

R Core Team (2020): R: A language and environment for statistical computing. Vienna, Austria. R Foundation for Statistical Computing. Version 3.6.1. https://cran.r-project.org/

Rodrigues, M. E., Roque, F. D. O., Guillermo-Ferreira, R., Saito, V. S. \& Samways, M. J. (2019). Egg-laying traits reflect shifts in dragonfly assemblages in response to different amount of tropical forest cover. Insect Conservation and Diversity, 12(3), 231-240. doi:10.1111/icad.12319

Shimano, Y. \& Juen, L. (2016). How oil palm cultivation is affecting mayfly assemblages in Amazon streams. Annales de Limnologie-International Journal of Limnology, 52, 35-45. doi:10.1051/ $\operatorname{limn} / 2016004$

Siegloch, A. E., Schmitt, R., Spies, M., Petrucio, M. \& Hernández, M. I. M. (2017). Effects of small changes in riparian forest complexity on aquatic insect bioindicators in Brazilian subtropical streams. Marine and Freshwater Research, 68(3), 519-527. doi:10.1071/MF15162

Sonter, L. J., Herrera, D., Barrett, D. J., Galford, G. L., Moran, C. J. \& Soares-Filho, B. S. (2017). Mining drives extensive deforestation in the Brazilian Amazon. Nature Communications, 8(1), 1-7. doi:10.1038/s41467-017-00557-w

Strahler, A. N. (1957). Quantitative analysis of watershed geomorphology. Eos, Transactions American Geophysical Union, 38(6), 913-920. doi:10.1029/TR038i006p00913

Valente-Neto, F., de Oliveira Roque, F., Rodrigues, M. E., Juen, L. \& Swan, C. M. (2016). Toward a practical use of Neotropical odonates as bioindicators: Testing congruence across taxonomic resolution and life stages. Ecological Indicators, 61, 952-959. doi:10.1016/j.ecolind.2015.10.052

Vianna, D. M. \& De Marco Jr, P. (2012). Higher-taxon and cross-taxon surrogates for odonate biodiversity in Brazil. Natureza and Conservação, 10(1), 34-39. doi:10.4322/natcon.2012.006

Wood, P. J. \& Armitage, P. D. (1997). Biological effects of fine sediment in the lotic environment. Environmental management, 21(2), 203-217. doi:10.1007/s002679900019

\section{Supplementary material}

Supplementary material S1. List of families and genera with the values of abundance $(\mathrm{N})$ and relative frequency (RF) of conformity of the suborders Anisoptera and Zygoptera recorded in the 30 streams sampled in the Capim river basin, in the municipality of Paragominas, Pará, Brazil.

Supplementary material S2. Loadings of the Redundancy Analysis with the local and regional predictors for the Odonata larvae assemblage structure in streams sampled in the Rio Capim river basin, on the municipality of Paragominas, Pará, Brazil.

Supplementary material S3. Results of RDA correlations for composition of Odonata larvae of streams sampled in the Rio Capim river basin, Paragominas, Pará, Brazil. Bolds values are correlations higher than 0.1 and -0.1 .

Supplementary material S4. Local habitat structure variables obtained from the protocol for the 30 streams sampled in the Rio Capim river basin, municipality of Paragominas, Pará, Brazil. Code, Mean and Standard deviation are informed. 